\title{
Perceived Oral Health Status and Its Association with Oral Health-Related Quality of Life of Patients with Rheumatoid Arthritis - A Pilot Study \\ (Persepsi Status Kesihatan Oral dan Sekutuannya dengan Kualiti Hidup Berkaitan Kesihatan Oral dalam Kalangan Pesakit Artritis Reumatoid - Suatu Kajian Awal)
}

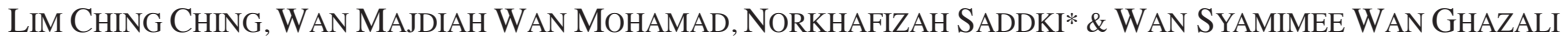

\begin{abstract}
Rheumatoid arthritis (RA) is an autoimmune disease that affects not only the joints, but also other organ systems including the oral cavity. Studies have demonstrated an association between RA and oral disease, in particular periodontal disease. This cross-sectional study aimed to determine self-reported oral health problems among RA patients and its association with oral health-related quality of life. A total of 67 RA patients attending the Rheumatology Clinic, Hospital Universiti Sains Malaysia participated in this study. Self-administered questionnaires including the Malay version of Short Oral Health Impact Profile [S-OHIP(M)] questionnaire were used to obtain the variables of interests. Most patients perceived their oral health status as good or very good (70.2\%) although some reported having at least one oral health problem (40.3\%). Commonly reported oral health problems were cavitated tooth (16.4\%), swollen gums (16.4\%), bad breath (14.9\%), and bleeding gums (13.4\%). Some patients have lost all upper teeth (32.8\%) and all lower teeth (28.4\%). The median S-OHIP(M) score was 3.00 (IQR 7.00). With regard to prevalence of impact, item discomfort due to food getting stuck has the highest prevalence of $13.4 \%$, followed by avoided eating certain foods (7.5\%). No significant association was found between median S-OHIP(M) score and self-reported oral health problem among RA patients, but a significant association was found between median S-OHIP $(M)$ score and perceived oral health status $(P=0.013)$. In conclusion, oral health problems were common in RA patients, and the association between patients' oral health perceptions and severity of impact from oral problems was apparent.
\end{abstract}

Keywords: Oral health; quality of life; rheumatoid arthritis

ABSTRAK

Artritis reumatoid $(R A)$ adalah penyakit autoimun yang menjejaskan bukan sahaja sendi, tetapi juga sistem organ lain termasuk kaviti oral. Kajian telah menunjukkan hubungan antara $R A$ dan penyakit oral, khususnya penyakit periodontium. Kajian keratan rentas ini bertujuan untuk menentukan masalah kesihatan oral dalam kalangan pesakit RA dan hubungannya dengan kualiti hidup berkaitan kesihatan oral. Sejumlah 67 orang pesakit RA yang hadir ke Klinik Reumatologi, Hospital Universiti Sains Malaysia mengambil bahagian dalam kajian ini. Borang soal selidik isi sendiri termasuk soal selidik Profil Impak Kesihatan Oral versi Bahasa Melayu [S-OHIP(M)] digunakan untuk memperoleh variabel yang diingini. Kebanyakan pesakit menganggap status kesihatan oral mereka sebagai baik atau sangat baik (70.2\%) walaupun sesetengah melaporkan mempunyai sekurang-kurangnya satu masalah kesihatan oral (40.3\%). Masalah kesihatan oral yang kerap dilaporkan adalah gigi berlubang (16.4\%), gusi bengkak (16.4\%), nafas berbau busuk (14.9\%) dan gusi berdarah (13.4\%). Sesetengah pesakit telah kehilangan semua gigi atas (32.8\%) dan semua gigi bawah (28.4\%). Skor median S-OHIP(M) adalah 3.00 (IQR 7.00). Berkenaan prevalens impak, item tidak selesa disebabkan makanan terlekat mempunyai prevalens tertinggi iaitu $13.4 \%$, diikuti dengan mengelak daripada memakan makanan tertentu (7.5\%). Tiada hubungan signifikan ditemui antara skor median S-OHIP(M) dan masalah kesihatan oral dalam kalangan pesakit RA, tetapi hubungan signifikan ditemui antara skor median S-OHIP(M) dan tanggapan status kesihatan oral (P=0.013). Sebagai kesimpulan, masalah kesihatan oral adalah kerap dalam kalangan pesakit $R A$ dan hubungan antara tanggapan kesihatan oral oleh pesakit dan keterukan impak daripada masalah kesihatan oral adalah jelas.

Kata kunci: Artritis reumatoid; kesihatan oral; kualiti hidup

\section{INTRODUCTION}

Rheumatoid arthritis (RA) is a chronic autoimmune disease characterized by synovial inflammation and hyperplasia, autoantibody production, cartilage and bone destruction as well as systemic involvement of other organ system or functions including cardiovascular, pulmonary, psychological and skeletal (McInnes et al.2011). Typically, RA manifests as symmetric arthritis involving numerous small and large joints. Articular symptoms may be accompanied by systemic inflammatory symptoms such as fatigue, articular stiffness, anorexia and fever (Cush et al. 2010). 
RA patients may have reduced health-related quality of life (HRQoL) as a result of painful interruption of the musculoskeletal system and related impairment of the motion sequence (Matcham et al. 2014). Additionally, the limited mobility of the wrist and finger joints may reduce patients' ability to perform oral hygiene care with subsequent increase in dental plaque accumulation which may increase inflammatory activity of the gingival tissues and risk of periodontitis (de Smit et al. 2015).

Periodontitis is an inflammatory disease caused by specific bacterial complexes in the dental plaque biofilm characterized by pocket formation and/or gingival recession, which may lead to periodontal ligament and alveolar bone loss (Al-Harthi et al. 2013). Severe periodontitis affects $5 \%$ to $15 \%$ of the general population and is considered to be a major health problem (Petersen 2008). Meanwhile, the most common periodontitis is mild to moderate form with prevalence ranging from $13 \%$ to $57 \%$ depending upon the case definition used (Corbet et al. 2002).

The association between RA and periodontal disease (PD) have been reported. RA patients have an increased risk for PD with more tooth loss and more clinical attachment loss than healthy individuals (Kaur et al. 2013). Oral manifestations found in RA patients such as secondary Sjogren syndrome, xerostomia, and temporomandibular joint disease have an increasing emphasis in patients with PD (Garib et al. 2011). RA and periodontitis also share many pathologic features. A similar profile of cytokines is involved in the pathogenesis of the two diseases (Rutger Persson 2012). It was suggested that disease activity of RA is correlated with serum levels of interleukin-6 (IL6), tumour necrosis factor-alpha (TNF- $\alpha$ ), and C-reactive protein (CRP), and it might influence bleeding on probing (BOP) of periodontal pockets in patients with moderate to high disease activity (Kobayashi et al. 2010). Additionally, a significant decrease in RA activity has been observed in RA patients who underwent periodontal treatment (Blaizot et al. 2013).

The negative impact of periodontitis on oral health related quality of life (OHRQoL) has been reported (AlHarthi et al. 2013). Considering that RA patients have an increased risk for $\mathrm{PD}$, it is thus possible that patients with RA may have reduced OHRQoL as well. The aim of this study was to determine self-reported oral health status and its association with OHRQoL among RA patients seen at Hospital Universiti Sains Malaysia (USM).

\section{MATERIALS AND METHODS}

This cross sectional study was carried out on 67 RA patients attending Rheumatology Clinic, Hospital USM, a teaching hospital located in the north-eastern of Peninsular Malaysia. The inclusion criteria were adult RA patients who can read and understand Bahasa Melayu. The exclusion criteria were mentally challenged or disabled patients. This study protocol was approved by the USM Human Research and Ethics Committee (USM/JEPeM/16030138).
The short version of the Malay Oral Health Impact Profile (S-OHIP(M)) was used to determine OHRQoL of participants. The tool was developed by Saub et al. (2005) following cross-cultural adaptation of the original English version of Oral Health Impact Profile (OHIP) into Malay language (Saub et al. 2007). The S-OHIP(M) contains 14 items arranged into seven domains (functional limitation, physical pain, psychological discomfort, physical disability, psychological disability, social disability and handicap) to measure the impact of oral conditions and diseases on life experiences.

A five-point Likert scale response format was used to assess the frequency of oral impact experienced by the patient within the past 12 months. The ordinal scale code ranges from ' 0 ' for 'never', ' 1 ' for 'hardly ever', ' 2 ' for 'occasionally', ' 3 ' for 'fairly often', and '4' for 'very often'. The sum of all ordinal response codes is the severity of impact experienced by the individual. The severity of impact may range from 0 to 56 and the mean severity score is the mean OHIP score. A higher OHIP score indicates poorer OHRQoL. Additionally, the prevalence of impact (the percentage of participants responding 'fairly often' or 'very often' to one or more items) was determined. We also collected data on socio-demographic background and perceived oral health status.

RA patients attending the Hospital USM Rheumatology Clinic during data collection period were screened for eligibility. Potential participants were selected using systematic random sampling method and were personally invited to participate in this study. The purpose of the study was explained to the patients, and written informed consent was obtained. Data collection was done at the waiting area of the clinic. The questionnaires were collected immediately upon completion. On average, the participants took approximately 10-15 minutes to answer all questions.

Data was entered and analysed using IBM (SPSS Statistics) version 24.0. Descriptive statistics were used to summarise the socio-demographic characteristics. Numerical data were presented as mean and standard deviation (SD) or median and interquartile range (IQR) based on their normality distribution. Categorical data were presented as frequency and percentage. Mann-Whitney test and Kruskal Wallis test were used to determine the differences in median S-OHIP(M) score by characteristics of participants.

\section{RESULTS}

Table 1 shows the socio-demographic characteristics of participants. The mean age was 53.8 years (SD 16.07). Most participants were female (83.6\%), and Malay was the predominant race $(86.6 \%)$. Most participants completed upper secondary education (41.8\%).

Their self-reported oral health status is shown in Table 2. Most RA patients perceived their oral health status as good $(64.2 \%)$ or very good $(6.0 \%)$ despite some of them reported having at least one oral health problem $(40.3 \%)$. The most common oral health problems were 
TABLE 1. Socio-demographic characteristics of study sample $(n=67)$

\begin{tabular}{lc}
\hline Variable & Frequency $(\%)$ \\
\hline Age group (years) & \\
$\leq 35$ & $11(16.4)$ \\
$36-55$ & $22(32.8)$ \\
$56-75$ & $29(43.3)$ \\
$>75$ & $5(7.5)$ \\
Sex & \\
Male & $11(16.4)$ \\
Female & $56(83.6)$ \\
Race & \\
Malay & $58(86.6)$ \\
Chinese & $5(7.5)$ \\
Indian & $2(3.0)$ \\
Others & $2(3.0)$ \\
Highest education level & \\
No formal education & $4(6.0)$ \\
Primary school & $11(16.4)$ \\
Lower secondary & $3(4.5)$ \\
Upper secondary & $28(41.8)$ \\
Post-secondary (Diploma/Vocational/equivalent) & $11(16.4)$ \\
Tertiary (Bachelor/Master/PhD) & $10(14.9)$ \\
\hline
\end{tabular}

TABLE 2. Self-reported oral health status $(n=67)$

\begin{tabular}{|c|c|}
\hline Variable & Frequency $(\%)$ \\
\hline \multicolumn{2}{|c|}{ Perceived oral health status } \\
\hline Very good & $4(6.0)$ \\
\hline Good & $43(64.2)$ \\
\hline Moderate & $17(25.4)$ \\
\hline Poor & $2(3.0)$ \\
\hline Very poor & $1(1.5)$ \\
\hline \multicolumn{2}{|c|}{ Presence of oral health problem } \\
\hline Yes & $27(40.3)$ \\
\hline No & $40(59.7)$ \\
\hline \multicolumn{2}{|c|}{ Oral health problem $(n=27)^{*}$} \\
\hline Toothache & $3(4.5)$ \\
\hline Cavitated tooth & $11(16.4)$ \\
\hline Gum pain & $1(1.5)$ \\
\hline Bleeding gum & $9(13.4)$ \\
\hline Gum abscess & $0(0.0)$ \\
\hline Swollen gum & $11(16.4)$ \\
\hline Mobile tooth & $4(6.0)$ \\
\hline Bad breath & $10(14.9)$ \\
\hline Other & $1(1.5)$ \\
\hline \multicolumn{2}{|l|}{ Lost all upper teeth } \\
\hline Yes & $22(32.8)$ \\
\hline No & $45(67.2)$ \\
\hline \multicolumn{2}{|l|}{ Lost all lower teeth } \\
\hline Yes & $19(28.4)$ \\
\hline No & $48(71.6)$ \\
\hline \multicolumn{2}{|l|}{ Wear upper denture } \\
\hline Yes & $34(50.7)$ \\
\hline No & $33(49.3)$ \\
\hline \multicolumn{2}{|l|}{ Wear lower denture } \\
\hline Yes & $21(31.3)$ \\
\hline No & $46(68.7)$ \\
\hline
\end{tabular}

*Multiple responses are allowable 
cavitated tooth (16.4\%) and swollen gums (16.4\%). These were followed by bad breath $(14.9 \%)$ and bleeding gums (13.4\%). Some participants have lost all their upper and/or lower teeth and were wearing upper and/or lower dentures.

The distribution of S-OHIP(M) scores was right skewed with a mean of 4.1 (SD 4.49) and a median of 3.00 (IQR 7). The prevalence of impact for all items are shown in Table 3. Discomfort from food getting stuck in between teeth or dentures has the highest prevalence of $13.4 \%$, followed by avoiding eating certain foods $(7.5 \%)$.

Table 4 shows differences in median S-OHIP(M) score by participants' characteristics. The median S-OHIP(M) scores were found to be significantly different between participants who perceived their oral health status as very good or good and participants who perceived their oral health status as moderate, poor or very poor. No significant difference was found in the median S-OHIP(M) scores between other patient characteristics including presence of oral health problem.

\section{DISCUSSION}

Most RA patients in this study perceived their oral health status as good $(64.2 \%)$ or very good $(6.0 \%)$. This is comparable to the results of the latest nationwide survey among general adults in Malaysian that showed more than half of adults $(52.4 \%)$ perceived their oral health status as good or excellent (Ministry of Health Malaysia 2013).
However, given the number of RA patients with at least one oral health problem in this study $(40.3 \%)$, this may mean either the problems were not severe enough to affect their life experiences or they have learned to live with the problems such that the impacts were largely ignored. Those experiencing symptoms for a longer duration may have a greater level of acceptance of their condition than those with recent disease onset. Although this is yet to be demonstrated in an RA population, research in other inflammatory conditions has found a significant association between disease duration and increased disease acceptance (Kiebles et al. 2010).

One of the most common oral health problem reported by RA patients in this study was cavitated tooth. Dental caries is a highly prevalent oral health problem among adult Malaysian population (Ministry of Health Malaysia 2013). This may also be the cause of the two most common impacts reported, discomfort due to food getting stuck and avoided eating certain foods. Another equally common oral health problem reported by the patients was swollen gums. This problem, as well as other frequently reported problems, bad breath and bleeding gum, are among the symptoms of PD, another common oral health problem reported among the adult population (Ministry of Health Malaysia 2013). PD symptoms reported among RA patients in this study may reflect the association between RA and PD as reported by previous studies.

TABLE 3. Prevalence of impact for each item

\begin{tabular}{lc}
\hline Variable & Frequency $(\%)$ \\
\hline Functional limitation & $2(3.0)$ \\
$\quad$ Difficulty chewing any foods & $0(0.0)$ \\
Problems caused bad breath & \\
& \\
Physical Pain & $2(3.0)$ \\
Discomfort eating any food & $0(0.0)$ \\
Ulcers in mouth & \\
& \\
Psychological Discomfort & $9(13.4)$ \\
Discomfort due to food getting stuck & $1(1.5)$ \\
Felt shy & \\
Physical disability & $5(7.5)$ \\
Avoided eating certain foods & $1(1.5)$ \\
Avoided smiling & \\
Psychological Disability & $0(0.0)$ \\
Sleep been disturbed & $0(0.0)$ \\
Concentration been disturbed & \\
Social disability & \\
Avoided going out & \\
Problems in carrying out daily activities & $0(0.0)$ \\
Handicap & $0(0.0)$ \\
Had to spend a lot of money & \\
Felt less confident & \\
\hline
\end{tabular}


TABLE 4. Differences in median S-OHIP(M) score by characteristics of participants

\begin{tabular}{|c|c|c|c|}
\hline Variable & Median (IQR) & $\mathrm{Z}$ statistic $(\mathrm{df})^{\mathrm{a}}$ & $\mathrm{P}$ value \\
\hline \multicolumn{4}{|l|}{ Age group (years) } \\
\hline$\leq 55$ & $2.00(9)$ & -0.140 & 0.889 \\
\hline$>55$ & $3.00(7)$ & & \\
\hline \multicolumn{4}{|l|}{ Sex } \\
\hline Male & $0.00(8)$ & -0.899 & 0.368 \\
\hline Female & $3.00(6)$ & & \\
\hline \multicolumn{4}{|l|}{ Ethnicity } \\
\hline Malay & $2.50(6)$ & -0.875 & 0.382 \\
\hline Others & $5.00(7)$ & & \\
\hline \multicolumn{4}{|l|}{ Highest education level } \\
\hline No formal/Primary & $2.00(3)$ & $5.22(2)^{\mathrm{b}}$ & $0.073^{\mathrm{c}}$ \\
\hline Secondary & $5.00(8)$ & & \\
\hline Post-secondary/Tertiary & $3.00(5)$ & & \\
\hline \multicolumn{4}{|l|}{ Perceived oral health status } \\
\hline Very good/Good & $2.00(6)$ & -2.489 & 0.013 \\
\hline Moderate/Poor/Very poor & $4.50(6)$ & & \\
\hline \multicolumn{4}{|l|}{ Presence of oral health problem } \\
\hline Yes & $4.00(8)$ & -1.837 & 0.066 \\
\hline No & $2.00(5)$ & & \\
\hline \multicolumn{4}{|l|}{ Lost all upper teeth } \\
\hline Yes & $3.00(8)$ & -0.473 & 0.636 \\
\hline No & $2.00(6)$ & & \\
\hline \multicolumn{4}{|l|}{ Lost all lower teeth } \\
\hline Yes & $3.00(8)$ & -0.479 & 0.632 \\
\hline No & $3.00(8)$ & & \\
\hline \multicolumn{4}{|l|}{ Wear upper denture } \\
\hline Yes & $3.50(7)$ & -1.003 & 0.316 \\
\hline No & $2.00(6)$ & & \\
\hline \multicolumn{4}{|l|}{ Wear lower denture } \\
\hline Yes & $3.00(8)$ & -0.219 & 0.827 \\
\hline No & $2.50(5)$ & & \\
\hline
\end{tabular}

Low median S-OHIP(M) scores of 3.00 (IQR 7) in this study suggests that the impact of problems experienced by the patients was mild. The mean S-OHIP(M) score among RA patients in this study was lower compared to patients with temporomandibular joint osteoarthritis (TMJ OA) reported by Su et al. (2016) which was 16.10 (SD 11.17). While TMJ $\mathrm{OA}$ is an age-related degenerative joint disease that results in progressive destruction of articular tissues in the TMJ condyle and glenoid fossa (Bag et al. 2014) compared to RA that manifests as a symmetric arthritis involving numerous small and large joints, the signs and symptoms of TMJ OA and RA are almost similar. This may indicate that oral health impacts were potentially underreported in RA patients and this is consistent with findings of previous studies among other patient population (Saddki et al. 2016).

Presence of oral symptoms has been found to be significantly associated with more negative impact and poorer OHRQoL among patients with juvenile idiopathic arthritis (Rahimi et al. 2018), the most common type of arthritis in children which can also cause persistent joint pain, swelling and stiffness (Barut et al. 2017). However, no significant association was found between the presence of oral symptoms and the severity of impact from oral conditions among RA patients in this study. Nevertheless, a significantly more severe impact was reported by patients who perceived their oral health status as moderate, poor, 
or very poor compared to those who perceived their oral health status as good or very good. While there is limited evidence on the association between individuals' perception of oral health and the impact of oral conditions on life experiences, the association between perceived oral health status and HRQoL has been indicated in numerous studies in different patient groups (Lee et al. 2007; Mohamed et al. 2017; Sandberg et al. 2003).

\section{CONCLUSION}

OHRQoL among RA patients was relatively good with mild oral impact. Oral health problems were common among RA patients, particularly symptoms of dental caries and PD, although most perceive their oral health condition as good or very good. The association between patients' oral health perceptions and severity of impact from oral problems was also apparent. We recommend general physicians to be aware of the susceptibility of RA patients to oral diseases particularly PD. Simple questions about the presence of related symptoms during clinical consultation may elucidate the presence of disease which should prompt immediate referral to dentists for further management. Early detection and treatment will not only improve outcome but also improve patients' OHRQoL.

Nevertheless, our sample was small, hence our results may not be generalisable to the target population due to reduced power of the study, and the limited sample may also explain for the failure to find differences in outcome. In addition, oral health problems reported by the patients in our study were self-assessed and thus should not be used as approximations for professional diagnoses. Some patients may not be aware of certain oral health problems or misinterpreted their symptoms.

\section{ACKNOWLEDGEMENTS}

The authors like to express our gratitude to the staff of the Rheumatology Clinic, Hospital USM. This study was funded by the USM Research University Grant (1001/ PPSG/812202).

\section{REFERENCES}

Al-Harthi, L.S., Cullinan, M.P., Leichter, J.W. \& Thomson, W.M. 2013. The impact of periodontitis on oral health-related quality of life: A review of the evidence from observational studies. Aust. Dent. J. 58(3): 274-277.

Bag, A.K., Gaddikeri, S., Singhal, A., Hardin, S., Tran, B.D., Medina, J.A. \& Curé, J.K. 2014. Imaging of the temporomandibular joint: An update. World J. Radiol. 6(8): 567-582.

Barut, K., Adrovic, A., Şahin, S. \& Kasapçopur, Ö. 2017. Juvenile idiopathic arthritis. Balkan Med.J. 34(2): 90-101.

Blaizot, A., Monsarrat, P., Constantin, A., Vergnes, J.N., de Grado, G.F., Nabet, C., Cantagrel, A. \& Sixou, M. 2013. Oral healthrelated quality of life among outpatients with rheumatoid arthritis. Int. Dent. J. 63(3): 145-153.

Corbet, E.F., Zee, K.Y. \& Lo, E.C. 2002. Periodontal diseases in Asia and Oceania. Periodontol 2000 29: 122-152.
Cush, J.J., Weinblatt, M.E. \& Kavanaugh, A. 2010. Rheumatoid Arthritis: Early Diagnosis and Treatment. 3rd ed. United States of America: Professional Communications, Inc.

de Smit, M.J., Westra, J., Brouwer, E., Janssen, K.M., Vissink, A. \& van Winkelhoff, A.J. 2015. Periodontitis and rheumatoid arthritis: What do we know? J. Periodontol. 86(9): 10131019.

Garib, B.T. \& Qaradaxi, S.S. 2011. Temporomandibular joint problems and periodontal condition in rheumatoid arthritis patients in relation to their rheumatologic status. J. Oral Maxillofac. Surg. 69(12): 2971-2978.

Kaur, S., White, S. \& Bartold, P.M. 2013. Periodontal disease and rheumatoid arthritis: A systematic review. J. Dent. Res. 92(5): 399-408.

Kiebles, J.L., Doerfler, B. \& Keefer, L. 2010. Preliminary evidence supporting a framework of psychological adjustment to inflammatory bowel disease. Inflamm. Bowel Dis. 16(10): 1685-1695.

Kobayashi, T., Murasawa, A., Komatsu, Y., Yokoyama, T., Ishida, K., Abe, A., Yamamoto, K. \& Yoshie, H. 2010. Serum cytokine and periodontal profiles in relation to disease activity of rheumatoid arthritis in Japanese adults. J. Periodontol. 81(5): 650-657.

Lee, I.C., Shieh, T.Y., Yang, Y.H., Tsai, C.C. \& Wang, K.H. 2007. Individuals' perception of oral health and its impact on the health-related quality of life. J. Oral Rehabil.34(2): 79-87.

Matcham, F., Scott, I.C., Rayner, L., Hotopf, M., Kingsley, G.H., Norton, S., Scott, D.L. \& Steer, S. 2014. The impact of rheumatoid arthritis on quality-of-life assessed using the SF36: A systematic review and meta-analysis. Semin. Arthritis Rheum. 44(2): 123-130.

McInnes, I.B. \& Schett, G. 2011. The pathogenesis of rheumatoid arthritis. N. Engl. J. Med. 365(23): 2205-2219. doi: doi: 10.1056/NEJMra1004965.

Ministry of Health Malaysia. 2013. National Oral Health Survey of Adults 2010 (NOHSA 2010). Kuala Lumpur: Oral Health Division, Ministry of Health Malaysia.

Mohamed, N., Saddki, N., Yusoff, A. \& Mat Jelani, A. 2017. Association among oral symptoms, oral health-related quality of life, and health-related quality of life in a sample of adults living with HIV/AIDS in Malaysia. BMC Oral Health 17(1): 119. doi: 10.1186/s12903-017-0409-y.

Petersen, P.E. 2008. World Health Organization global policy for improvement of oral health--World Health Assembly 2007. Int. Dent. J. 58(3): 115-121.

Rahimi, H., Twilt, M., Herlin, T., Spiegel, L., Pedersen, T.K., Küseler, A. \& Stoustrup, P. 2018. Orofacial symptoms and oral health-related quality of life in juvenile idiopathic arthritis: A two-year prospective observational study. Pediatr. Rheumatol. Online J. 16(1): 47. doi: 10.1186/s12969-0180259-4.

Rutger Persson, G. 2012. Rheumatoid arthritis and periodontitis - inflammatory and infectious connections. Review of the literature. J. Oral Microbiol. 4(2012). doi: 10.3402/jom. v4i0.11829.

Saddki, N. \& Yong, K.Y. 2016. Self-reported oral health problems and oral health-related quality of life in Malay women living with HIV/AIDS. Malaysian Journal of Public Health Medicine 16(3): 241-248.

Sandberg, G.E. \& Wikblad, K.F. 2003. Oral health and healthrelated quality of life in type 2 diabetic patients and nondiabetic controls. Acta Odontol. Scand. 61(3): 141-148. 
Saub, R., Locker, D., Allison, P. \& Disman, M. 2007. Crosscultural adaptation of the Oral Health Impact Profile (OHIP) for the Malaysian adult population. Community Dent. Health 24(3): 166-175.

Saub, R., Locker, D. \& Allison, P. 2005. Derivation and validation of the short version of the Malaysian Oral Health Impact Profile. Community Dent. Oral Epidemiol. 33(5): 378-383.

Su, N., Liu, Y., Yang, X., Shen, J. \& Wang, H. 2016. Correlation between oral health-related quality of life and clinical dysfunction index in patients with temporomandibular joint osteoarthritis. J. Oral. Sci. 58(4): 483-490.

Lim Ching Ching, Wan Majdiah Wan Mohamad \& Norkhafizah Saddki*

School of Dental Sciences

Universiti Sains Malaysia, Health Campus

16150 Kubang Kerian, Kelantan Darul Naim

Malaysia
Wan Syamimee Wan Ghazali

Department of Medicine, School of Medical Sciences

Universiti Sains Malaysia, Health Campus

16150 Kubang Kerian, Kelantan Darul Naim

Malaysia

Wan Majdiah Wan Mohamad, Norkhafizah Saddki* \& Wan Syamimee Wan Ghazali

Hospital Universiti Sains Malaysia, Health Campus

16150 Kubang Kerian, Kelantan Darul Naim

Malaysia

*Corresponding author; email: fizah@usm.my

Received: 15 April 2019

Accepted: 7 October 2019 